\title{
Analisis Peramalan Permintaan dan Pengendalian Persediaan Bahan Baku Pembantu pada Industri Gula (Studi Kasus PT. XYZ Lampung Utara)
}

\author{
Analysis Forecasting Dem \& Control of Supply Raw Materialsi In The \\ Sugar Industry (Case Study of PT. XYZ North Lampung)
}

Dharma Agista Pratama, Sri Hidayati*, Erdi Suroso, Dewi Sartika

University of Lampung/ Agricultural Technology

*E-mail : srihidayati.unila@gmail.com

\begin{abstract}
Forecasting \& inventory management is one of the important factors in determining the sustainability of a business in an industry. The research objective is to analyze the sales forecasting method most suitable for the sugar industry of PT. XYZ \& analyze inventory control techniques using the Economic Order Quantity (EOQ) method. There are 5 forecasting methods used, namely: Linear Regression, Moving Average, Weighted Moving Average, Exponential Smoothing, \& exponential smoothing with trend. The analysis shows that the linear regression method is the most suitable forecasting method used by the sugar industry of PT. XYZ with the smallest MAD, MSE, \& MAPE values compared to other methods is 7,195, 65,854,060, \& 10\%, with forecast results in 2019 of 44,746 tons of granulated sugar. The results of the analysis of inventory control using the EOQ method of sulfur auxiliary raw materials \& caustic soda. The frequency of ordering for sulfur is done 28 times per year having a total inventory cost of $R p .1,010,908,000$ \& cost savings of $R p$. 19,581,365. \& causatic soda helpers with a frequency of ordering 27 times per year having a total inventory cost of Rp. 922,241,500 \& cost savings of Rp. 17,840,930.
\end{abstract}

Keywords: EOQ, Sales Forecasting, Inventory Control

Disubmit: 16 Juli 2020; Diterima: 23 Juli 2020; Disetujui: 6 Agustus 2020

\section{PENDAHULUAN}

PT. XYZ merupakan salah satu BUMN yang bergerak dibidang agroindustry pengolahan gula tebu mulai dari penanaman tanaman tebu, pengolahan bahan baku tebu di pabrik, pengepakan hasil jadi sampai dengan penjualan gula pasir sebagai produk akhir. Industri gula PT. XYZ masih melakukan pemesanan secara konvensional, dimana pemesanan dilakukan berdasarkan kebiasaan atau pengalaman dari periode sebelumnya. Pemesanan yang dilakukan secara konvensional dapat mengakibatkan sering terjadinya kerusakan barang akibat kelebihan stok barang dan menambah pengeluaran untuk biaya penyimpanan. Persediaan bahan baku pembantu pada industri gula merupakan faktor penting guna kelancaran proses produksi sehingga perlu dilakukan suatu perencanaan untuk mengefisienkan persediaan baik secara ekonomi maupun kuantitas. Perencanaan jumlah persediaan yang akan dimiliki perusahaan merupakan salah satu masalah yang sering dihadapi perusahaan. Persediaan merupakan salah satu faktor penting yang dapat menunjang proses produksi perusahaan maupun membantu memenuhi permintaan pelanggan.Bagi 
perusahaan yang memiliki strategi make to stock, persediaan dapat memberikan dampak besar padapenetapan harga dari produk ataupun keuangan perusahaan (Sipper dan Bulfin, 1998). Manajemen persediaan yang tepatdapat menjadi salah satu kunci untuk meminimasi maupun mengoptimasi biaya yang akan dikeluarkan perusahaan (Tersine, 1994). Persediaan sebagai kekayaan perusahaan, memiliki peranan penting dalam operasi bisnis. Oleh karena itu persediaan yang baik diperlukan untuk menunjang proses produksi (Dania et al, 2012).

Perencanaan persediaan bahan baku pembantu diperlukan peramalan permintaan gula. Pada PT XYZ, semua produksi gula terserap oleh permintaan sehingga data permintaan merupakan data yang diperoleh dari penjualan gula. Peramalan penjualan gula diperlukan untuk mengetahui jumlah bahan baku pembantu yang dibutuhkan. Peramalan permintaan merupakan tingkat permintaan produkyang diharapkan akan terealisir pada masa yang akan datang melalui pengujian keadaan di masa lalu (Hariati et al, 2012; Mandala dan Darnila, 2017; Nasution dan Prasetyawan, 2008). Menurut (Sofyan, 2013), metode peramalan kuantitatif dikelompokkan menjadi dua jenis yaitu metode deret waktu atau time series dan metode kausal. Peramalan (forecasting) dengan peramalan kuantitatif dilakukan menggunakan metode Linear Regression (Yanti, et al, 2016), Moving Average (Nurlifa dan Kusumadewi, 2017). Weighted Moving Average, Exponential Smoothing (Wardah, 2016) dan Exponential Smoothing with Trend. Peramalan bertujuan mendapatkan peramalan (forecast )yang bias meminimumkan kesalahan meramal (forecast error)yang biasanya diukur dengan MSE (Mean Squared Error), MAE (Mean Absolute Error), dan sebagainya (Subagyo, 1986). Peramalan terbaik ditentukan dengan pengukuran relatif yang bertujuan untuk mengetahui besar kesalahan pada setiap metode peramalan. Pengukuran relatif dilakukan dengan menghitung nilai Mean Absolute Deviation (MAD), Mean Squared Error (MSE), dan Mean Absolute Percentage Error (MAPE). Metode peramalan dengan nilai MAD, MSE, dan MAPE terkecil merupakan metode peramalan yang paling tepat digunakan pada industri gula PT. XYZ.

Hasil peramalan penjualan gula yang diperoleh digunakan sebagai acuan dalam perencanaan pengendalian persediaan bahan baku pembantu. Salah satu metode yang digunakan untuk perencanaan pengendalian adalah menggunakan metode Economic Order Quantity (EOQ). Tujuan model ini adalah untuk menentukan jumlah optimum setiap kali pemesanan sehingga meminimumkan biaya persediaan. Persediaan yang terlalu besar (over stock) merupakan pemborosan karena menyebabkan terlalu tingginya beban-beban biaya guna penyimpanan dan pemeliharaan selama penyimpanan di gudang (Iqbal et al, 2017). Metode Economic Order Quantity (EOQ) merupakan metode perencanaan persediaan satu tahun yang dilakukan dengan cara meminimalkan ongkos pesan dan ongkos simpan (Sofyan, 2013). (Fadlallh, 2015), menyatakan bahwa penerapan EOQ bertujuan untuk mengefisienkan persediaan bahan baku sesuai dengan kebijakan perusahaan sedangkan (Amarillah et al, 2016) menerapkan metode EOQ untuk bahan pembantu pada pabrik gula di pabrik gula Ngadirejo. Bahan pembantu pada industri pengolahan gula adalah belerang, kaustik soda, kapur, asam fosfat, dan flokulan. Belerang digunakan dalam bentuk gas sulfit $\left(\mathrm{SO}_{2}\right)$ untuk proses pemurnian nira mentah pada proses sulfitasi. Causatic soda merupakan bahan kimia yang digunakan untuk membersihkan evaporator. Baroto (2002) menyatakan bahwa model persediaan diklasifikasikan menjadi dua yaitu metode $\mathrm{P}$ dan metode $\mathrm{Q}$. Dilihat dari permintaannya model $E O Q$ terbagi atas dua model yaitu model $E O Q$ dengan kebutuhan deterministik dan model $E O Q$ dengan kebutuhan probabilistik (Makridakis et al, 1999). Model $E O Q$ deterministik adalah model persediaan dengan permintaan tetap dan dari waktu ke waktu bersifat konstan atau telah diketahui dengan pasti. Sedangkan model EOQ probabilistic adalah model persediaan dimana permintaan barang tidak diketahu isebelumnya dan selalu berubah-ubah sehingga besarnya permintaan mengikuti suatu distribusi peluang tertentu. Tujuan penelitian adalah Menganalisis metode peramalan penjualan yang paling sesuai untuk industri gula PT. XYZ dan menganalisis 
teknik pengendalian persediaan menggunakan Metode Economic Order Quantity (EOQ) sehingga diharapkan dapat mengurangi pengeluaran perusahaan untuk persediaan.

\section{METODE PENELITIAN}

Penelitian dilakukan dengan cara mengumpulkan data melalui survei, pengamatan, telaah pustaka, dan diskusi/brainstormingdengan para pakar. Jenis data yang akan dikumpulkan dalam penelitian ini yaitu data sekunder yang diperoleh melalui penelusuran pustaka, wawancara atau laporan dari industri gula PT. XYZ . Analisis data yang dilakukan pada penelitian ini meliputi peramalan penjualan (forecasting), pengukuran relatif, dan pengendalian persediaan. Pengukuran peramalan penjualan (forecasting), pengukuran relatif, dan pengendalian persediaan menggunakan Software POM-QM for Windows Version 3. Analisis peramalan penjualan (forecasting) menggunakan beberapa metode yaitu Linear Regression, Moving Average, Weighted Moving Average, Exponential Smoothing, dan exponential smoothing with trend dan pengukuran relative menggunakan Mean Absolute Deviation (MAD), Mean Squared Error (MSE) dan Mean Absolute Percentage Error (MAPE). Pengukuran relatif digunakan untuk mengetahui besar kesalahan sebuah peramalan. Pengukuran relatif digunakan untuk mengetahui besar kesalahan sebuah peramalan. Peramalan dilakukan dengan cara melibatkan data penjualan gula pasir PT. XYZ di masa lalu dan menempatkannya ke masa yang akan datang dengan menggunakan Software POM-QM for Windows Version 3. Manajemen persdiaan dilakukan dengan menggunakan metode Economic Order Quantity (EOQ).

Linear Regression. Regresi adalah sebuah metode matematika untuk menggambarkan hubungan antar variabel. Model regresi yang paling sederhana melibatkan sebuah variabel tak bebas dan sebuah variabel bebas (Assauri, 2004). Menurut (Bahagia, 2006), bentuk model Linear Regression adalah :

$\mathrm{Y}^{\prime}=\mathrm{a}+\mathrm{bX}$

Keterangan:

$Y^{\prime} \quad=$ Nilai yang diramalkan

a $\quad=$ Konstanta (intercept)

$\mathrm{b} \quad=$ Koefisien regresi (slope)

$\mathrm{X} \quad=$ Variabel yang mempengaruhi (waktu: tahun, bulan, hari)

Moving Average. Metode peramalan Moving Average merupakan peramalan yang didasarkan pada rata-rata aritmatika yang didapatkan dari data pada masa lampau. Teknik peramalan permintaan menggunakan Moving Average diperkiran dengan menghitung rata-rata permintaan aktual dari jumlah tertentu pada periode sebelumnya (Baroto, 2002). Menurut (Gitosudarmo, 2002), bentuk dari metode Moving Average adalah :

$\mathrm{Y}_{[+1}^{\prime}=\frac{\mathrm{T}_{[-\mathrm{n}+1}+\cdots+\mathrm{T}_{[+1}+\mathrm{T}_{\mathrm{I}}}{\mathrm{n}}$

Keterangan:

$\mathrm{Y}^{\prime}{ }_{\mathrm{L}+1} \quad=$ Nilai peramalan periode $\mathrm{t}+1$

$\mathrm{T}_{\mathrm{t}} \quad=$ Nilai rill periode ke-t

$\mathrm{n} \quad=$ Jumlah deret waktu yang digunakan

Weighted Moving Average. Metode peramalah Weighted Moving Average merupakan peramalan lebih lanjut dari Moving Average dimana setiap deret waktu lampau diberikan bobot tertentu dan mungkin diberi bobot yang berbeda-beda (Handoko, 2014). Menurut (Heizer \& Render, 2010), bentuk dari metode Weighted Moving Average adalah: 
$Y_{\mathrm{I}}^{\prime}=\frac{\mathrm{W}_{1} \mathrm{~A}_{\mathrm{I}-1}+\mathrm{W}_{\mathrm{L}} \mathrm{A}_{\mathrm{I}-2}+\cdots+\mathrm{W}_{\mathrm{n}} \mathrm{A}_{\mathrm{I}-\mathrm{n}}}{\mathrm{n}}$

Keterangan:

$Y_{\mathrm{I}}^{\prime} \quad=$ Nilai peramalan periode $\mathrm{t}$

$\mathrm{W}_{1}$ = Bobot yang diberikan pada periode $\mathrm{t}-1$

$\mathrm{W}_{2} \quad$ = Bobot yang diberikan pada periode $\mathrm{t}-2$

$\mathrm{W}_{\mathrm{n}} \quad=$ Bobot yang diberikan pada periode $\mathrm{t}-\mathrm{n}$

$\mathrm{n} \quad=$ Jumlah periode

Exponential Smoothing. Metode Exponential Smoothing adalah suatu prosedur yang secara terus menerus memperbaiki peramalan (smoothing) dengan merata-ratakan nilai masa lalu dari suatu data deret waktu dengan cara menurun (exponential) (Indrajit \& Djokopranoto, 2003). Menurut (Nasution, Hakim \& Prasetyawan, 2008), bentuk model Exponential Smoothing adalah:

$\mathrm{S}_{\mathrm{I}}=\alpha * \mathrm{Xt}+(1-\alpha) * S_{[-1}$

Keterangan:

$S_{L} \quad=$ Peramalan untuk periode $\mathrm{t}$

$\mathrm{S}_{\mathrm{I}-1} \quad=$ Peramalan pada waktu $\mathrm{t}-1$

$\alpha \quad=$ Konstanta perataan antara 0 dan 1

$\mathrm{Xt}+(1-\alpha)=$ Nilai aktual time series

Exponential Smoothing with Trend. Model Exponential Smoothing with Trend merupakan salah satu analisis Exponential Smoothing yang menganalisa deret waktu, dan merupakan metode peramalan dengan memberi nilai pembobot pada serangkaian pengamatan sebelumnya untuk memprediksi masa depan (Rangkuti, 2004). Menurut (Ristono, 2009), bentuk model Exponential Smoothing with Trend adalah :

$\mathrm{T}_{\mathrm{I}}=\beta\left(\mathrm{S}_{\mathrm{I}}-\mathrm{S}_{\mathrm{I}-1}\right)+(1-\beta) \mathrm{T}_{\mathrm{I}-1}$

Keterangan:

$\mathrm{T}_{\mathbf{L}} \quad=$ Peramalan untuk periode $\mathrm{t}$

$\mathrm{T}_{\mathrm{I}-\mathrm{I}} \quad=$ Peramalan pada waktu $\mathrm{t}-1$

$\beta \quad=$ Konstanta dengan nilai antara 0 dan 1

$\mathrm{S}_{\mathrm{I}} \quad=$ Permintaan nyata periode $\mathrm{t}$

$\mathrm{S}_{\mathrm{I}-\mathrm{I}} \quad=$ Permintaan nyata periode $\mathrm{t}-1$

Mean Absolute Deviation (MAD). Mean Absolute Deviation (MAD) merupakan ukuran utama dari kesalahan perkiraan dari seluruh model peramalan. Nilai eror dihitung dengan membagi jumlah nilai absolut dari kesalahan perkiraan dengan jumlah periode. Mean Absolute Deviation (MAD) paling berguna ketika orang yang menganalisa ingin mengukur kesalahan ramalan dalam unit yang sama sebagai deret asli.

$\mathrm{MAD}=\frac{\sum|D-F|}{\mathrm{n}}$

Keterangan:

$D \quad=$ Nilai yang sebenarnya pada masa-t

$\mathrm{Ft} \quad=$ Nilai yang diramalkan pada masa-t

$n \quad=$ jumlah masa yang dicakup

Hal 151 Volume 20 Nomor 2 , Tahun 2020 
Mean Squared Error (MSE). Mean Squared Error (MSE) adalah metode lain untuk mengevaluasi metode peramalan. Masing-masing kesalahan atau sisa dikuadratkan. Kemudian dijumlahkan dan dibagi dengan jumlah observasi. Pendekatan ini mengatur kesalahan peramalan yang besar karena kesalahankesalahan itu dikuadratkan. Kelemahan dari menggunakan Mean Squared Error (MSE) adalah bahwa ia cenderung untuk menonjolkan penyimpangan besar karena istilah kuadrat.

$$
\operatorname{MSE}=\frac{\sum(D-F)^{2}}{\mathrm{n}}
$$

Keterangan:

$$
\begin{array}{ll}
\text { Dt } & =\text { Nilai yang sebenarnya pada masa-t } \\
\mathrm{Ft} & =\text { Nilai yang diramalkan pada masa-t } \\
\mathrm{n} & =\text { jumlah masa yang dicakup }
\end{array}
$$

Mean Absolute Percentage Error (MAPE). Masalah dengan MAD dan MSE adalah bahwa nilai-nilai mereka bergantung pada besarnya item yang diperkirakan. Jika item yang diramalkan dalam ribuan, maka MAD dan MSE bisa sangat besar. Untuk menghindari masalah tersebut, kita dapat menggunakan metode Mean Absolute Percentage Error (MAPE). MAPE mengindikasi seberapa besar kesalahan dalam meramal yang dib\&ingkan dengan nilai nyata pada deret. Metode MAPE digunakan untuk memb\&ingkan ketepatan dari teknik yang sama atau berbeda dalam dua deret yang sangat berbeda dan mengukur ketepatan nilai dugaan model yang dinyatakan dalam bentuk rata-rata persentase absolut kesalahan. MAPE dapat dihitung dengan rumus sebagai berikut:

MAPE $=\frac{\sum|D-F|}{\sum D}$

Keterangan:

Dt = Nilai yang sebenarnya pada masa-t

$\mathrm{Ft} \quad=$ Nilai yang diramalkan pada masa-t

Economic Order Quantitiy (EOQ). Metode Economic Order Quantity (EOQ) merupakan metode perencanaan persediaan satu tahun yang dilakukan dengan cara meminimalkan ongkos pesan dan ongkos simpan (Fadlallh, 2015; Sofyan, 2013), menyatakan bahwa penerapan EOQ bertujuan untuk mengefisienkan persediaan bahan baku sesuai dengan kebijakan perusahaan. Sedangkan menurut (Baroto, 2002), model persediaan diklasifikasikan menjadi dua yaitu metode $\mathrm{P}$ dan metode $\mathrm{Q}$. Metode $\mathrm{Q}$ terdiri dari banyak model dengan salah satu modelnya adalah metode EOQ. Menurut (Rangkuti, 2004), EOQ dapat dihitung menggunakan rumus sebagai berikut:

$$
\mathrm{EOQ}=\sqrt{\frac{2 \mathrm{DS}}{\mathrm{H}}}
$$

\section{Keterangan:}

EOQ = Jumlah pemesanan ekonomis

$\mathrm{S} \quad=$ Biaya setiap kali pesan

$\mathrm{D}=$ Jumlah kebutuhan bahan baku dalam satu periode produksi

$\mathrm{H} \quad$ = Biaya penyimpanan dinyatakan dalam persentase dari persediaan rata-rata bahan baku

Menurut Wahyuni dan Achmad (2015), persentase biaya penyimpanan dapat dihitung berdasarkan persentase harga item yang disimpan di gudang dengan rincian sebagai berikut: 


$\begin{array}{ll}>\text { Biaya kerusakan dan kehilangan } & : 1 \% \text { dari harga item } \\ >\text { Biaya penanganan persediaan } & : 0,5 \% \text { dari harga item } \\ >\text { Biaya fasilitas penyimpanan } & : 0,5 \% \text { dari harga item } \\ >\text { Persentase biaya penyimpanan } & : 2 \% \text { dari harga item }\end{array}$

\section{HASIL DAN PEMBAHASAN}

Peramalan Penjualan Gula Pasir. PT. XYZ memproduksi gula pasir dimulai pada bulan juni sampai pada kira-kira 6 bulan untuk masa tebu giling dan produksi gula pasir. Penjualan gula PT. XYZ dilakukan dengan menjual secara eksklusif kepada Perusahaan Umum Badan Urusan Logistik (Perum Bulog). Selanjutnya Perum Bulog yang akan mendistribusikan gula ke masyarakat. Jumlah gula yang dijual PT. XYZ tergantung dengan jumlah produksi gula yang mampu dihasilkan oleh PT. XYZ setiap tahunnya. Data yang digunakan untuk melakukan peramalan yaitu data penjualan gula pasir PT. XYZ tahun 2013-2018. Data hasil peramalan tersaji pada Tabel 1.

Tabel 1. Hasil peramalan penjualan gula pasir PT. XYZ

\begin{tabular}{|c|c|c|c|c|c|c|}
\hline No & Metode peramalan & & MAD & MSE & MAPE & $\begin{array}{l}\text { Peramalan } \\
2019\end{array}$ \\
\hline 1 & Linear Regression & & 7.195 & 65.854 .060 & $10 \%$ & 44.746 \\
\hline 2 & Moving Average & & 10.448 & 160.108 .000 & $15 \%$ & 53.311 \\
\hline 3 & $\begin{array}{l}\text { Wighted Moving } \\
\text { Average }\end{array}$ & & 11.857 & 240.109 .600 & $20 \%$ & 53.090 \\
\hline \multirow[t]{3}{*}{4} & \multirow[t]{3}{*}{ Eksponential Smoting } & $\alpha=0,3$ & 15.280 & 280.360 .000 & $25 \%$ & 64.633 \\
\hline & & $\alpha=0,6$ & 12.484 & 217.052 .900 & $20 \%$ & 56.155 \\
\hline & & $\alpha=0,9$ & 10.745 & 171.554 .000 & $16 \%$ & 53.382 \\
\hline \multirow[t]{3}{*}{5} & \multirow[t]{3}{*}{$\begin{array}{l}\text { Eksponential } \\
\text { Smoothing With Trend }\end{array}$} & $\alpha=0,9 \quad \beta=0,3$ & 12.098 & 187.118 .000 & $18 \%$ & 47.342 \\
\hline & & $\alpha=0,9 \beta=0,6$ & 12.588 & 211.914 .500 & $18 \%$ & 46.576 \\
\hline & & $\alpha=0,9 \beta=0,9$ & 14.500 & 233.090 .800 & $22 \%$ & 50.178 \\
\hline
\end{tabular}

Keterangan : - MAD (Mean Absolute Deviation)

- MSE (Mean Squared Error)

- MAPE (Mean Absolute Percentage Error)

Metode linear regression memiliki nilai MAD, MSE, dan MAPE terkecil dari metode lainnya yaitu sebesar 7.195, 65.854.060, dan 10\%, dengan hasil peramalan pada tahun 2019 sebesar 44.746 ton gula pasir. Oleh karena itu, metode linear regression merupakan metode peramalan yang paling tepat digunakan PT. XYZ untuk memprediksi penjualan gula di masa yang akan datang. Hasil penelitian Prasetio (2014), menyatakan bahwa peramalan penjualan jas hujan dengan menggunakan metode linear regression memiliki nilai MAD dan MSE terendah dibandingkan dengan metode moving average,wighted moving average,eksponential smoothing, dan eksponential smoothing with trend. Selaras dengan pendapat (Djie, 2013), menyatakan bahwa peramalan penjualan produk polo shirt dengan menggunakan metode linear regression memiliki nilai MAD dan MSE terendah dib\&ingkan dengan metode moving average,wighted moving average,eksponential smoothing, dan eksponential smoothing with trend. Sedangkan hasil penelitian (Yulius, H., \&Yetti, 2014), menyatakan bahwa peramalan kebutuhan manajemen logistik pada usaha depot air minum isi ulang Al-Fitrah dengan menggunakan metode linear regression memiliki nilai MAD dan MSE terendah dib\&ingkan dengan metode moving average, wighted moving average, dan eksponential smoothing.

Peramalan penjualan gula pasir PT. XYZ menggunakan metode linear regression disajikan pada Gambar 3. Berdasarkan Gambar 3, diketahui bahwa penjualan gula pasir pada tahun 2013 sebesar 77.356 
ton dan mengalami peningkatan penjualan gula pasir pada tahun 2014 menjadi 90.900 ton. Namun, penjualan gula pasir terus mengalami penurunan pada tahun 2015, 2016, 2017, dan 2018 berturut-turut sebesar 84.870 ton, 63.120 ton, 52.758 ton, dan 53.311 ton.

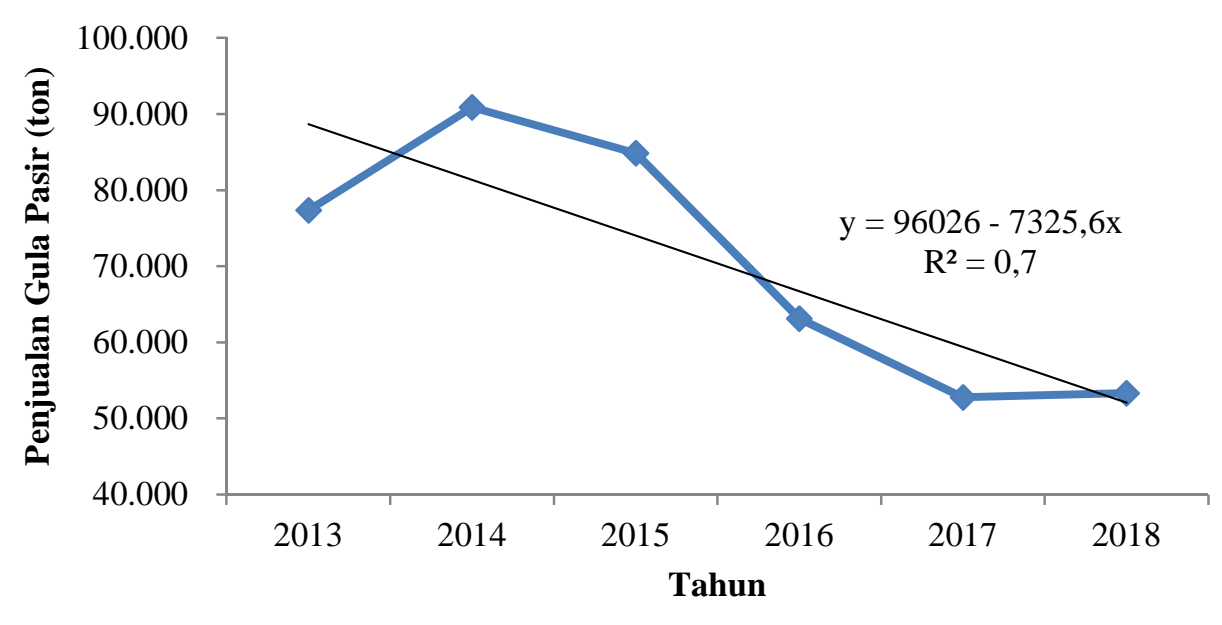

Gambar 1. Peramalan penjualan gula pasir PT. XYZ menggunakan metodelinear regression

Pada Gambar 1, diketahui nilai regresi yang dihasilkan pada peramalan penjualan gula pasir di PT. $\mathrm{XYZ}$ menggunakan metode linear regression sebesar $\mathrm{y}=96026-7325,6 \mathrm{x}$ dengan akurasi pembacaan $\mathrm{R}^{2}=$ 0,7. Hal tersebut menunjukkan bahwa tren penjualan gula pasir di PT. XYZ mengalami penurunan. Hasil peramalan penjualan gula pasir di PT.XYZ pada tahun 2019 - 2023 disajikan pada Tabel 2.

Tabel 2. Peramalan penjualan gula pasir PT.XYZ pada tahun 2019 - 2023

\begin{tabular}{cccccc}
\hline \multirow{2}{*}{ Item } & \multicolumn{5}{c}{ Peramalan (Ton/Tahun) } \\
& 2019 & 2020 & 2021 & 2022 & 2023 \\
\hline Penjualan Gula Pasir & 44.746 & 37.420 & 30.095 & 22.769 & 15.443 \\
\hline
\end{tabular}

Validasi Metode Peramalan dan Realisasi Produksi. Validasi metode peramalan dan realisasi produksi merupakan perb\&ingan antara jumlah produksi gula pasir hasil peramalan tahun 2019 dengan jumlah realisasi produksi gula pasir di PT. XYZ tahun 2019. Grafik validasi metode peramalan dan realisasi produksi di PT. XYZ disajikan pada Gambar 2.

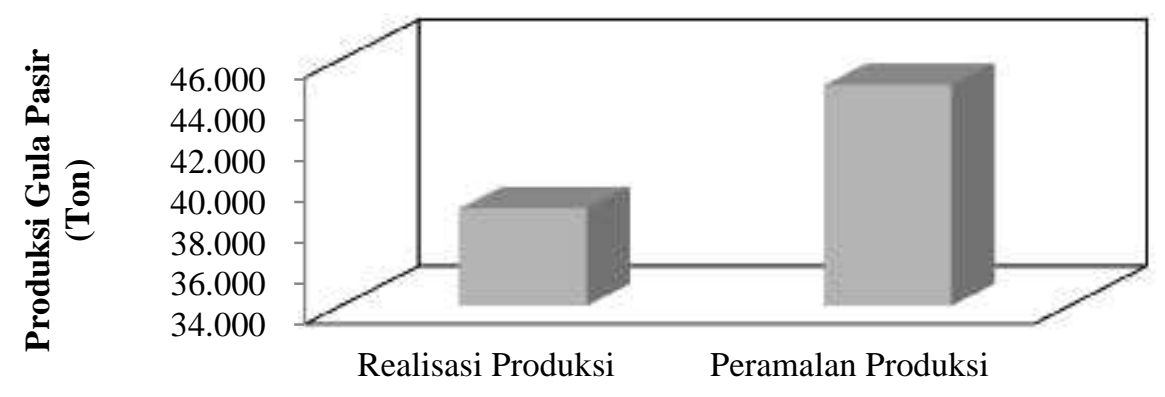

Tahun 2019

Gambar 2. Grafik validasi metode peramalan dan realisasi produksi di PT. XYZ 
Manajemen Persediaan. Manajemen persediaan merupakan kegiatan perencanaan, pelaksanaan, pengawasan, dan penentuan kebutuhan bahan baku yang memerlukan biaya persediaan (Indrajit \& Djokopranoto, 2003). Menurut (Handoko, 2014), Biaya persediaan merupakan biaya yang timbul akibat adanya persediaan bahan baku yang terdiri dari biaya pemesanan (Setup Cost atau Ordering Cost), dan biaya penyimpanan (Holding Cost). Dalam melakukan pemesanan kepada Vendor terdapat kesepakatan antara PT. XYZ dengan vendor, dimana harga bahan baku pembantu yang ditawarkan oleh vendor merupakan harga untuk keseluruhan proses pengiriman barang hingga masuk pada gudang perusahaan. Biaya pemesanan pada PT. XYZ adalah biaya yang timbul akibat adanya biaya yang dikeluarkan untuk pemesanan bahan baku pembantu seperti biaya telepon, printing dokumen, dan biaya internet untuk email dan browsing sebesar Rp. 27.450. Perhitungan biaya pemesanan belerang dan causatic soda disajikan pada Lampiran 4. Sedangkan biaya penyimpanan timbul akibat adanya biaya yang dikeluarkan untuk penyimpanan bahan baku pembantu. Biaya penyimpanan belerang dan causatic soda disajikan pada Tabel 3.Manajemen persediaan yang digunakan pada penelitian ini yaitu menggunakan metode Economic Order Quantity (EOQ), dan konvensional.

Tabel 3. Biaya penyimpanan bahan baku pembantu belerang dan causatic soda

\begin{tabular}{cccc}
\hline $\begin{array}{l}\text { Bahan Baku } \\
\text { Pembantu }\end{array}$ & $\begin{array}{c}\text { Harga Item } \\
(\mathrm{Rp} / \mathrm{Kg})\end{array}$ & Persentase & $\begin{array}{c}\text { Biaya Penyimpanan } \\
(\mathrm{Rp} / \mathrm{Kg})\end{array}$ \\
\hline Belerang & 4.359 & $2 \%$ & 87 \\
Caustic soda & 15.456 & $2 \%$ & 309 \\
\hline
\end{tabular}

Metode Economic Order Quantity (EOQ). Metode Economic Order Quantity (EOQ) pada pengendalian persediaan bahan baku pembantu digunakan untuk menganalisa jumlah pemesanan ekonomis pada bahan baku pembantu yang masuk kategori A yaitu belerang dan causatic soda. Analisis EOQ membutuhkan beberapa komponen perhitungan diantaranya adalah permintaan bahan baku pembantu tahunan, biaya pemesanan, biaya penyimpanan, dan harga bahan baku per item. Satuan item yang digunakan pada belerang dan causatic soda adalah kg. Hasil kebutuhan bahan baku pembantu dengan menggunakan metode EOQ disajikan pada Tabel 4.

Tabel 4. Kebutuhan optimum dengan menggunakan EOQ

\begin{tabular}{lcccc}
$\begin{array}{c}\text { Bahan Baku } \\
\text { Pembantu }\end{array}$ & $\begin{array}{c}\text { Permintaan } \\
(\mathrm{Kg} / \text { Tahun })\end{array}$ & $\begin{array}{c}\text { Biaya Pemesanan } \\
\text { (Rp/Pesan) }\end{array}$ & $\begin{array}{c}\text { Biaya } \\
\text { Penyimpanan } \\
(\mathrm{Rp} / \mathrm{Kg})\end{array}$ & $\mathrm{Q}(\mathrm{Kg} / \mathrm{Pesan})$ \\
\hline Belerang & 231.750 & 12.450 & 87 & 8.136 \\
Caustic soda & 59.625 & 12.450 & 309 & 2.192 \\
\hline
\end{tabular}

Hasil perhitungan Economic Order Quantity (EOQ) bahwa jumlah pesanan optimal (Q) untuk bahan baku pembantu belerang yaitu sebesar $8.136 \mathrm{~kg}$ per pesan, dan bahan baku pembantu causatic soda sebesar $2.192 \mathrm{~kg}$ per pesan. Grafik hasil perhitungan Q pada bahan baku pembantu belerang dan causatic soda disajikan pada Gambar 3 dan Gambar 4. 


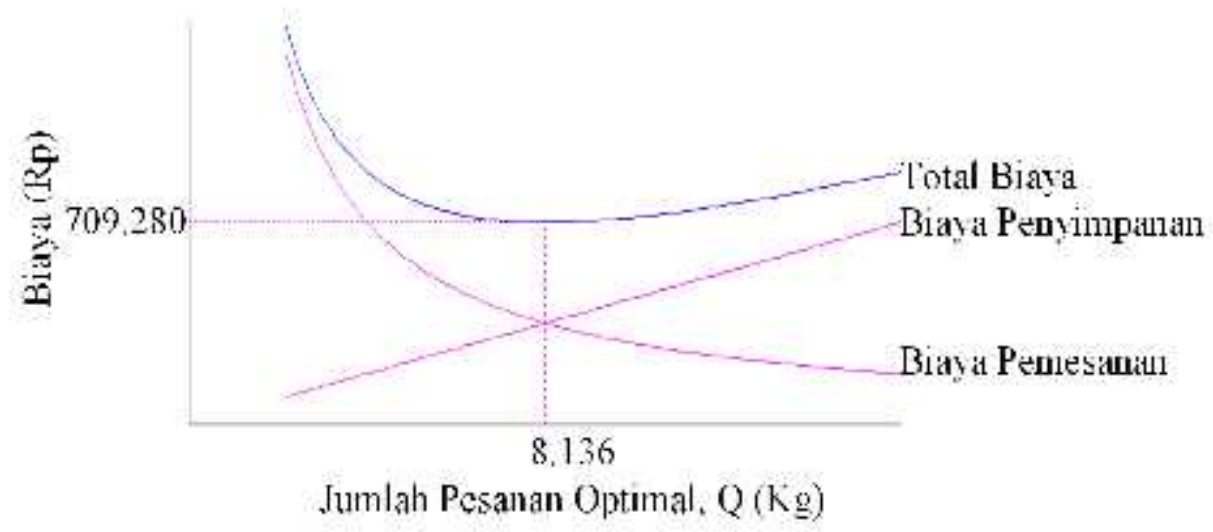

Gambar 3. Grafik EOQ bahan baku pembantu belerang

Pada Gambar 3, diketahui jumlah pesanan optimal (Q) bahan baku pembantu belerang sebesar 8.136 $\mathrm{kg}$ didapat dari hasil perpotongan biaya penyimpanan (holding cost) dan biaya pemesanan (setup cost), sehingga didapatkan total biaya penyimpanan dan pemesanan bahan baku pembantu belerang sebesar Rp. 709.280. 709.280.

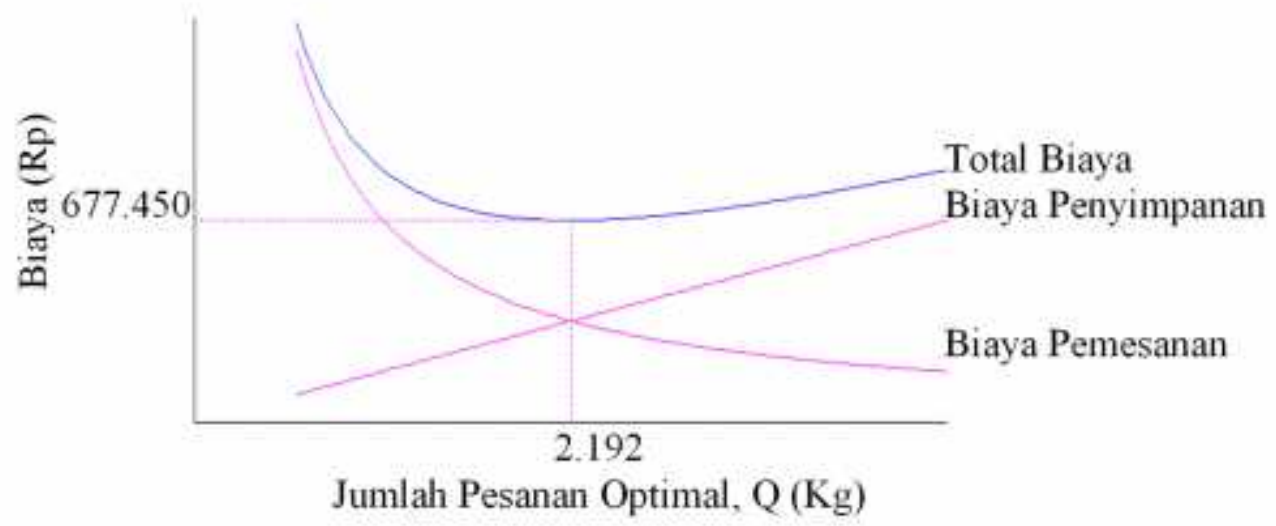

Gambar 4. Grafik EOQ bahan baku pembantu causatic soda

Jumlah pesanan optimal (Q) bahan baku pembantu causatic soda sebesar $2.192 \mathrm{~kg}$ didapat dari hasil perpotongan biaya penyimpanan (holding cost) dan biaya pemesanan (setup cost), sehingga didapatkan total biaya penyimpanan dan pemesanan bahan baku pembantu causatic soda sebesar Rp. 677.450.Setelah Q diketahui dilakukan perhitungan untuk mengetahui berapa kali dilakukan pemesanan dalam satu tahun. Komponen yang diperlukan untuk menghitung frekuensi waktu pemesanan adalah Q, permintaan tahunan, dan jumlah hari kerja. Perhitungan frekuensi waktu pemesanan disajikan pada Tabel 5.

Tabel 5. Perhitungan jumlah frekuensi waktu pemesanan optimum

\begin{tabular}{lcrcc}
\hline $\begin{array}{c}\text { Bahan Baku } \\
\text { Pembantu }\end{array}$ & $\mathrm{Q}(\mathrm{Kg} /$ Pesan $)$ & $\begin{array}{r}\text { Permintaan } \\
(\text { Kg/Tahun })\end{array}$ & Hari Kerja & $\begin{array}{c}\text { Frekuensi } \\
\text { Pemesanan }\end{array}$ \\
\hline Belerang & 8.136 & 231.750 & 264 & 28 \\
Caustic soda & 2.192 & 59.625 & 264 & 27 \\
\hline
\end{tabular}

Bahan baku pembantu belerang dengan jumlah pemesanan optimum $8.136 \mathrm{~kg}$ dalam satu tahun dilakukan pemesanan sebanyak 28 kali. Sedangkan bahan baku pembantu causatic soda dengan jumlah pemesanan optimum $2.192 \mathrm{~kg}$ dalam satu tahun dilakukan pemesanan sebanyak $27 \mathrm{kali}$. Total biaya 
persediaan minimum bahan baku pembantu belerang sebesar Rp. 1.010.908.000 dan total biaya persediaan minimum bahan baku pembantu causatic soda sebesar Rp. 922.241.500. Hasil penelitian (Rahmawati et al, 2017), menunjukkan bahwa metode EOQ pada manajemen persediaan bahan baku tebu di pabrik gula madukusumo bantul dapat membuat total biaya persediaan per musim giling menjadi lebih hemat. Hasil tersebut sejalan dengan penelitian (Kushartini dan Almahdy, 2016), bahwa metode EOQ pada sistem persediaan bahan baku produk dispersant $\mathrm{X}$ mendapatkan biaya penyimpanan yang rendah sehingga dapat meminimalkan biaya persediaan yang dikeluarkan perusahaan setiap tahunnya.

Metode PT. XYZ Secara Konvensional. PT. XYZ dalam melakukan pengendalian persediaan bahan baku pembantu masih menggunakan cara konvensional atau berdasarkan pengalaman. Perhitungan total biaya persediaan yang dilakukan oleh PT. XYZ tidak menggunakan metode perhitungan khusus. Pengendalian persediaan bahan baku pembantu di PT. XYZ membutuhkan beberapa komponen perhitungan diantaranya adalah data pembelian dan pemakaian bahan baku pembantu tahunan, harga bahan baku per item, biaya pemesanan, dan biaya penyimpanan. Data pembelian bahan baku pembantu belerang dan causatic soda di PT. XYZ disajikan pada Tabel 6, data pemesanan pada Tabel 7, biaya penyimpanan (Tabel 8) dan biaya persediaan (Tabel 9).

Tabel 6. Pembelian Bahan Baku Pembantu Belerang dan Causatic Soda

\begin{tabular}{lccr}
\hline $\begin{array}{c}\text { Bahan Baku } \\
\text { Pembantu }\end{array}$ & $\begin{array}{c}\text { Harga Item } \\
(\mathrm{Rp} / \mathrm{Kg})\end{array}$ & $\begin{array}{c}\text { Pembelian } \\
(\mathrm{Kg})\end{array}$ & $\begin{array}{c}\text { Pembelian Item } \\
(\mathrm{Rp} / \text { Tahun })\end{array}$ \\
\hline Belerang & 4.359 & 231.750 & 1.010 .198 .000 \\
Caustic soda & 15.456 & 59.625 & 921.564 .000 \\
\hline
\end{tabular}

Tabel 71. Total biaya pemesanan

\begin{tabular}{lccc}
\hline $\begin{array}{l}\text { Bahan Baku } \\
\text { Pembantu }\end{array}$ & $\begin{array}{l}\text { Frekuensi } \\
\text { Pembelian }\end{array}$ & $\begin{array}{l}\text { Biaya Pemesanan } \\
\text { (Rp/Pemesanan) }\end{array}$ & $\begin{array}{l}\text { Total Biaya } \\
\text { Pemesanan } \\
\text { (Rp/Tahun) }\end{array}$ \\
\hline Belerang & 7 & 12.450 & 87.150 \\
Caustic soda & 7 & 12.450 & 87.150 \\
\hline
\end{tabular}

Tabel 82. Biaya Penyimpanan

\begin{tabular}{lrrrr}
\hline Bahan baku & $\begin{array}{c}\text { Harga Item } \\
(\mathrm{Rp} / \mathrm{Kg})\end{array}$ & $\begin{array}{c}\text { Persentase } \\
(\%)\end{array}$ & $\begin{array}{c}\text { Pembelian } \\
(\mathrm{Kg})\end{array}$ & \begin{tabular}{c}
\multicolumn{1}{c}{$\begin{array}{c}\text { Biaya } \\
\text { Penyimpanan } \\
(\mathrm{Kg} / \text { Tahun })\end{array}$} \\
\hline Belerang
\end{tabular} \\
Caustic soda & 4.359 & $2 \%$ & 231.750 & 20.203 .965 \\
\hline
\end{tabular}

Tabel 93. Biaya Persediaan

\begin{tabular}{lcccc}
\hline $\begin{array}{c}\text { Bahan Baku } \\
\text { Pembantu }\end{array}$ & $\begin{array}{c}\text { Pembelian Item } \\
\text { (Rp/Tahun) }\end{array}$ & $\begin{array}{c}\text { Biaya } \\
\text { Pemesanan } \\
\text { (Rp/Tahun) }\end{array}$ & $\begin{array}{c}\text { Biaya } \\
\text { Penyimpanan } \\
\text { (Rp/Tahun) }\end{array}$ & $\begin{array}{c}\text { Biaya } \\
\text { Persediaan } \\
\text { (Rp/Tahun) }\end{array}$ \\
\hline Belerang & 1.010 .198 .000 & 87.150 & 20.203 .965 & 1.030 .489 .365 \\
Caustic soda & 921.564 .000 & 87.150 & 18.430 .280 & 940.082 .430 \\
\hline
\end{tabular}

Berdasarkan Tabel 9, dapat diketahui bahwa biaya persediaan bahan baku pembantu belerang yang dikeluarkan selama satu tahun yaitu sebesar Rp. 1.030.489.365. Sedangkan biaya persediaan bahan baku pembantu causatic soda yang dikeluarkan selama satu tahun sebesar Rp. 940.082.430. Perbandingan total Hal 157 Volume 20 Nomor 2 , Tahun 2020 
Jurnal Penelitian Pertanian Terapan

persediaan bahan baku pembantu belerang dan causatic soda antara perhitungan PT. XYZ dengan Metode EOQ disajikan pada Tabel 10.

Tabel 10. Perbandingan total biaya persediaan bahan baku pembantu

\begin{tabular}{lllll}
\hline Metode & $\begin{array}{l}\text { Bahan Baku } \\
\text { Pembantu }\end{array}$ & $\begin{array}{l}\text { Frekuensi } \\
\text { Pembelian }\end{array}$ & $\begin{array}{l}\text { Total Biaya } \\
\text { Persediaan } \\
\text { (Rp/Tahun) }\end{array}$ & $\begin{array}{l}\text { Biaya } \\
\text { Penghematan } \\
\text { (Rp/Tahun) }\end{array}$ \\
\hline PT. XYZ & Belerang & 7 & 1.030 .489 .365 & - \\
EOQ & Caustic soda & 7 & 940.082 .430 & - \\
& Belerang & 28 & 1.010 .908 .000 & 19.581 .365 \\
& Caustic soda & 27 & 922.241 .500 & 17.840 .930 \\
\hline
\end{tabular}

Metode EOQ dengan frekuensi pemesanan 28 kali per tahun memilikitotal biaya persediaan sebesar Rp. 1.010.908.000 dan biaya penghematan sebesar Rp. 19.581.365. Pada Tabel 17, dapat diketahui pula bahwa metode pengendalian persediaan bahan baku pembantu causatic soda dengan frekuensi pemesanan 27 kali per tahun memiliki total biaya persediaan sebesar Rp. 922.241 .500 dan biaya penghematan sebesar Rp. 17.840 .930 .

\section{KESIMPULAN}

Metode peramalan yang paling tepat digunakan PT. XYZ untuk memprediksi penjualan gula di masa yang akan datang.adalah metode Linear Regression dengan nilai MAD, MSE, dan MAPE terkecil dari metode lainnya yaitu sebesar 7.195, 65.854.060, dan 10\%, dengan hasil peramalan pada tahun 2019 sebesar 44.746 ton gula pasir. Metode EOQ pada bahan baku pembantu belerang dengan frekuensi pemesanan 28 kali per tahun memilikitotal biaya persediaan sebesar Rp. 1.010.908.000 dan biaya penghematan sebesar Rp. 19.581.365. dan pembantu causatic soda dengan frekuensi pemesanan 27 kali per tahun memiliki total biaya persediaan sebesar Rp. 922.241.500 dan biaya penghematan sebesar Rp. 17.840.930.

\section{DAFTAR PUSTAKA}

Amarillah, A. F., Zahroh, Z. A., dan Maria, G. W. E. N. P. 2016. Analisis metode economic order quantity (eoq) sebagai dasar pengendalian persediaan bahan baku pembantu (studi pada PG. Ngadirejo KediriPT. Perkebunan Nusantara X). Jurnal Administrasi Bisnis Universitas Brawijaya, 33, 35-42.

Assauri, S. 2004. Manajemen Produksi dan Operasi. Jakarta: Fakultas Ekonomi Universitas Indonesia Bahagia, S. N. (2006.

Bahagia, S. N. 2006. Sistem Inventory. Bandung: Institut Teknologi Bandung.

Baroto, T. 2002. Perencanaan dan Pengendalian Produksi. Jakarta: Ghalia Indonesia.

Dania, W. A. P., U.Effendi, U., dan Anggasta, F. 2012. Aplikasi Just-In-Time pada perencanaan dan pengendalian persediaan kentang (studi kasus di perusahaan Agronas Gizi Food Batu). Industria, 1, 2230.

Djie. 2013. Analisis peramalan penjualan dan penggunaan metode linear programing dan decision tree guna mengoptimalkan keuntungan pada PT Primajaya Pantes Garment. The Winners, 14, 113-119.

Fadlallh, A. W. 2015. The effect of applying the economic order quantity model in the field of inventory. International Journal Of Management (IJM), 6, 9-18. 
Pratama, Sri Hidayati, Erdi Suroso, D ewi Sartika : Analisis Peramalan Permintaan dan Pengendalian......

Gitosudarmo, H. I. 2002. Manajemen Operasi. Yogyakarta: Universitas Gajah Mada.

Handoko, T. H. 2014. Dasar Dasar Manajemen Produksi dan Operasi. Yogyakarta: BPFE-Yogyakarta.

Hariati, I.P., Deoranto, P., dan Dewi, I. A. 2012. Peramalan pemintaan produk keripik tempe CV Aneka Rasa dengan metode jaringan syaraf tiruan. Industria, 1, 10-21.

Heizer, J., dan Render, B. 2010. Manajemen Operasi Edisi 9. Jakarta: Salemba Empat.

Indrajit, R. E., dan Djokopranoto, R. 2003. Manajemen Persediaan Barang Umum dan Suku Cadang Untuk Keperluan Pemeliharaan Perbaikan dan Operasi. Jakarta: Grasindo.

Iqbal, T., Aprizal., D., \& Wali, M. 2017. Aplikasi manajemen persediaan barang berbasis Economic Order Quantity (EOQ). Teknologi Informasi Dan Komunikasi Universitas Syah Kuala, 1, 1-60.

Kushartini, D., dan Almahdy, I. 2016. Sistem persediaan bahan baku produk dispersant di industri kimia. PASTI Universitas Mercu Buana, 10, 217-243.

Makridakis, S., Wheelwright, S. C., McGee, dan Victor, E. 1999. Metode dan Aplikasi Peramalan.Jilid Satu.(Edisi 2) diterjemahkan oleh Andriyanto, U.S., Abdul, A. Jakarta: Erlangga.

Mandala, R., dan Darnila, E. 2017. Peramalan persediaan optimal beras menggunakan model Economic Order Quantity (EOQ) pada UD. Jasa Tani. Jurnal Ilmiah Sistem Informasi, 1, 127-156.

Nasution, Hakim, A., dan Prasetyawan, Y. 2008. Perencanaan dan Pengendalian Produksi Edisi Pertama. Jakarta: Graha Ilmu.

Nurlifa, A., dan Kusumadewi, S. 2017. Sistem peramalan jumlah penjualan menggunakan metode moving average pada rumah jilbab Zaky. Jurnal Inovtek Polbeng Seri Informatika, 2, 21-25.

Rahmawati, R., Rahayu, E. S., \& Ani, S. W. 2017. Analisis penerapan Economic Order Quantity (EOQ) di pabrik gula Madukismo Bantul. Journal of Sustainable Agriculture Universitas Sebelas Maret, 32, 126-131.

Rangkuti, F. 2004. Manajemen Persediaan Aplikasi di Bidang Bisnis. Jakarta: Raja Grafindo Persada.

Ristono, A. 2009. Manajemen Persediaan Edisi Pertama. Yogyakarta: Graha Ilmu.

Sipper, D dan Bulfin, R, L. 1998. Production: Planning, Control \& Integration, International Edition. USA: The McGraw-Hill Companies, Inc.

Sofyan, D. K. 2013. Perencanaan dan Pengendalian Produksi Edisi Pertama. Yogyakarta: Graha Ilmu.

Subagyo, P. 1986. Forcesting Konsep \& Aplikasi. Yogyakarta: BPFE-UGM.

Tersine, R. J. 1994. Principles of Inventory \& Material Management. New Jersey: Prentice-Hall, Englewood Cliffs.

Wardah, S. \& I. 2016. Analisis peramalan penjualan produk keripik pisang kemasan bungkus (studi kasus : home industry Arwana Food Tembilahan). Jurnal Teknik Industri, 9, 135-142.

Yanti, N. P. L. P., Tuningrat, I. A. M., dan Wiranatha, A. A. P. A. 2016. Analisis peramalan penjualan produk kecap pada perusahaan kecap Manalagi Denpasar Bali. Jurnal Rekayasa Dan Manajemen

Hal 159 Volume 20 Nomor 2 , Tahun 2020 
Jurnal Penelitian Pertanian Terapan

Agroindustry, 4, 72-81.

Yulius, H.,dan Yetti, I. 2014. Peramalan kebutuhan manajemen logistik pada usaha depot air minum isi ulang Al Fitrah. Jurnal Edik Informatika Universitas Putra Indonesia Padang, 1, 5-14. 